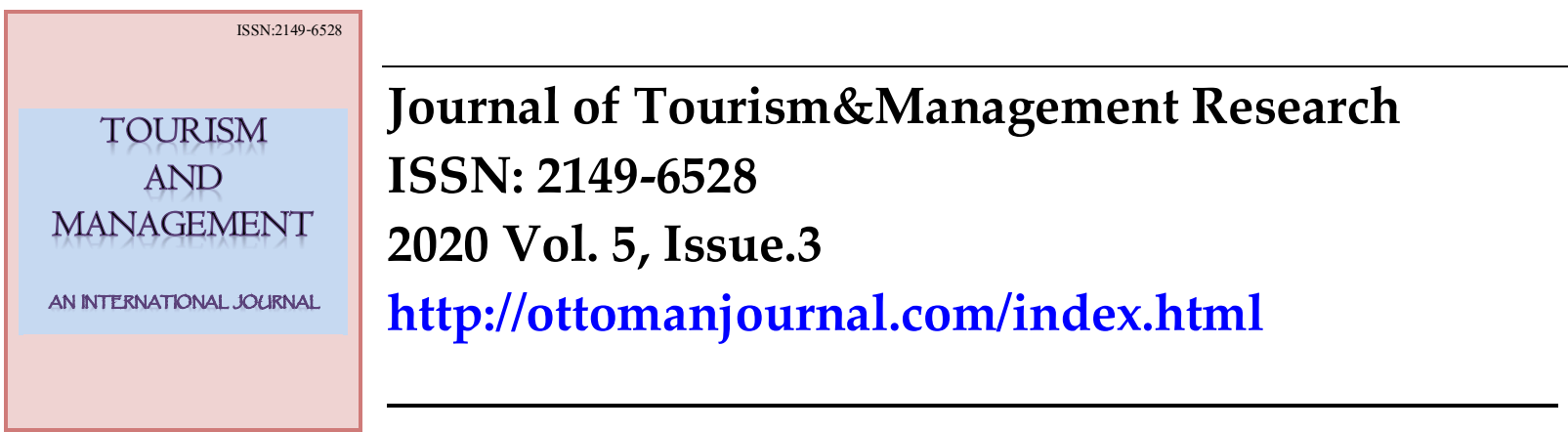

\title{
Investigating the Effects of Covid-19 pandemic on Narok County's Tourism and Hospitality Sectors
}

\begin{abstract}
Tourism and hospitality sectors are one of the biggest economic pillars of Narok county, Kenya. This study was conducted to examine the exact level and nature of the effects of Covid-19 pandemic on the sector in Narok county. A cross-sectional design of study was used. Questionnaires, interview guides and observations were used for data collection. The findings indicated that over $70 \%$ of the clients were non-willing to resume with tourism activities after the pandemic is over. Some of the stakeholders had partially or fully changed their profession. The average number of clients visiting tourism destination sites had reduced by $84 \%$ within 3 months. The clients had changed their perception of preference, with economy and safety being preferred over comfort. As a result, their mode of transaction and travel had changed. There was no significant change in the preferred tourism destination sites $(P<0.05)$. The stakeholders net profit margins had reduced from in excess of Ksh. 40,000 to less than Ksh. 10,000 per month. It was concluded that the sector had truly been ravaged by the pandemic. The stakeholders recommend cushioning in form of tax-waivers, monthly stipends or incentives from the county and national government.
\end{abstract}

Keywords: Tourism and hospitality sector, Covid-19 pandemic, stakeholders, Narok county, economy

JEL codes: E60, F22, O55, Z30

Submitted: 30/08/2020; Accepted:30/11/2020

Morompi Ole Masago. PhD Candidate. Department of Curriculum Instruction and Education Management, Maasai Mara University, Kenya. P.O Box 861-20500.

Email: morompi@mmarau.ac.ke

Sambu Alice, PhD. Department of Social Studies, Religion and Community Development, Maasai Mara University, Kenya. P.O Box 861-20500.

Email: asamba@mmarau.ac.ke

Kweingoti G. Reuben. Department of Social Studies, Religion and Community Development, Maasai Mara University, Kenya. P.O Box 861-20500.

Email: kweingoti@mmarau.ac.ke 
Keiza S. Kinzi. Department of Tourism and Hospitality Management, Maasai Mara University, P.O Box 861-20500, Narok Kenya.

Email: kinzisam92@gmail.com

Bakari Chaka (Corresponding Author). Department of Mathematics and Physical Sciences, Maasai

Mara University, Kenya. P.O Box 861-20500, Narok, Kenya. Tel: +254705350166

Email: bakarichaka@yahoo.com

\section{Introduction}

Tourism and hospitality industry is one of the economic pillars of the Kenyan economy (Njoya and Seetaram, 2018). The sector has continued to steer the economy by revenue generation as well as job creation. This sector provides millions of jobs to Kenyan youth both directly and indirectly. The World Travel and Tourism Council (WTTC) estimates that this sector has employed around 330 million people globally (WTTC, 2020a). The sector is also credited for over $10.3 \%$ of the worlds, gross domestic product, GDP (WTTC, 2020a). In Kenya, the sector has been gradually growing leading to more jobs and GDP. The sector grew by $3.9 \%$ from 2018 to 2019 (WTTC, 2020a).

In the past, global tourism has been affected by pandemics and other global crises. There have been several mild pandemics in the last half-century with immediate and long-term effects to tourism. The Severe Acute Respiratory Syndrome (SARS) outbreak of 2003 significantly reduced tourism activities globally (Gossling et al., 2020). There were less air and sea travels recorded in that year affecting the tourism industry. The Swine Flu of 2009 led to loss of about 1 million tourists in Mexico (Gossling et al., 2020). An approximated 2.8 billion US dollars were lost in that year (World Bank, 2020). In 2015, the Middle East Respiratory Syndrome (MERS) outbreak reduced global travels and thus tourism activity in that year (Siu and Wong, 2004). Waves of The Ebola disease outbreak have caused a negative perception of tourism destination sites in Democratic Republic of Congo, DRC (Maphanga \& Henama, 2019; Novelli et al., 2018).

With the onset of Covid-19 pandemic at the beginning of 2020, the Kenyan government shut all air travels in March, 2020. By extension, foreign tourists (who account for majority of the tourists in Narok) could not travel to the county. Soon thereafter, more travel restrictions were put in Kenya, especially through hotspot regions such as Nairobi and the coastal towns. These restrictions limited the number of tourists wishing to tour the county. With a strained economy and looming health pandemic with no known cure or vaccine, very few people if any dared to go to the tourism destinations. Actually, people were encouraged to stay and if possible, work from home to avoid contracting the dreaded corona virus. Tourism and hospitality industry in the county were thus dealt a major blow.

This study sought to bring into light the exact situation of tourism and hospitality sector in Narok county at the time of the pandemic. The month of study (June) was chosen since this was the hardest hit in terms of travel restrictions and economy. The findings obtained will go a long way in informing policy makers on the exact decisions to make (where, how and why to put more resources) as they plan to open up the sector. This will minimize panic-driven decisions which can later turn to be costly.

While the implications of Covid-19 seemed almost obvious, there was very little data of the exact figures pertaining tourism and hospitality sector. The percentage changes in tourists, number and types of tourism destination sites closed, auxiliary services closed, effect on the immediate community etc. was lacking. This can be attributed to closure of research facilities and institutions as well as panic by researchers (opting for their safety over research). However, such data is very essential in informing policy makers and stakeholders of these industries on the re-opening plans. 


\section{Literature Review}

\subsection{Covid-19 Pandemic}

A pandemic is an outgrown blast of an infectious disease across a large region (Bloom and Cadarette, 2019). The diseases in question often originate from a single locus and spread out very quickly (Bloom and Cadarette, 2019). Previous notable pandemics include The Black Death (The Plague) of $14^{\text {th }}$ century and the Spanish Flu of 1918 (Cohn, 2012). Pandemics usually strain the health system of a nation causing high mortalities. This force the governments of the affected nations to restrict movement of people in order to curb the infections. Only essential service providers are allowed to move freely in such times.

The novel corona virus responsible for the deadly SARS-COV-2 disease (popularly termed as Covid-19) originated in Wuhan region of China (Mackenzie and Smith, 2020). The first case of the disease was reported on $31^{\text {st }}$ December, 2019. Pneumonia-like symptoms were observed in the patients. In early January 2020, 41 patients from Wuhan region were confirmed to have the infections and admitted to hospital (Mackenzie and Smith, 2020). It was then that the disease started posing potential catastrophic indicators and Wuhan region was put under lockdown to try and curb its spread. Unfortunately, the virus had already leaked out and travelled to other parts of China and the world (Sharma et al., 2020). By March 2020, the number of infections had alarmingly increased globally and The World Health Organization (WHO) declared Covid-19 disease a global pandemic. By then, more than 140 countries in all continents had already confirmed the infections (Sharma et al., 2020).

Since there were no known pharmaceutical interventions such as drugs and vaccines, most countries resolved to other non-pharmaceutical measures. There was restricted movement of people, mandatory quarantine for suspects of the disease and isolation of infected individuals. Some public health measures such as social-distancing, wearing of masks and regular handwashing or sanitization of surfaces were greatly advocated. With travel restrictions, the tourism and hospitality industries were greatly affected. Tourists could no longer visit their destination sites due to restricted movement, closure of these facilities and reduced spending due to unforeseen economic times ahead.

\subsection{Effects of Covid-19 Pandemic on Tourism and Hospitality Industries}

Restriction of movement implied tourists could not move from their homes to tourism destination sites. As the infections of Covid-19 continued to increase exponentially, most public gatherings were also banned (WTTC, 2020b). Some of the social gatherings were tourism destination sites. For example, casinos and sites of sports-tourism draw many tourists from different geographical locations. With time, other destination sites closed for fear of its employees acquiring the infections or gaps in the tourism and hospitality sector chain. This sector is integrated into other sectors such as transport, communication, food amongst many other sectors. People were urged to stay and work from home and move out only when necessary.

Many countries with tourists who had visited other countries urged their citizens to resume back to their countries. Tourists who had visited countries perceived to have vulnerable health care systems such as African countries were even air-lifted out of these countries. Most of the African countries were perceived to have little capacity to test for the infections and take care of infected individuals. Within weeks, most tourists in Africa (and Kenya in particular) had left. Numerous gaps started appearing in the tourism and hospitality industries. There were cancelled events, closed accommodations, shut down tourism attraction sites as well as sharp reduction in supply of catering services (IMF, 2020). All these factors combined to bring the sector to its knees. 


\subsection{Tourism in Narok}

The county enjoys a vast savannah terrain with natural serenities, diverse wild animals and birds and a rich cultural heritage from its natives, The Maa community (Morompi et al., 2020; Ogutu et al., 2016). The biggest tourism destination in Narok is the great Maasai mara national reserve. This destination is one of the worlds' greatest attraction site due to its diverse wild life activities (Western et al., 2009). The site is also one of the leading tourism destinations in Kenya, alongside the coastal beaches. All the big five game animals are found in Maasai mara national reserve; at ease and with abundance (Gakuya et al., 2012). The wildebeest migration that take place annually between July and August is a spectacular view to watch. In this event, over a million wildebeests and a few zebras cross Mara river as they move from Kenya to Tanzania (Serengeti National Park) (Dobson, 2009). Thousands of tourist's visit the county to witness and film these wonder of the world.

Apart from Maasai mara national reserve, the county has a rich cultural heritage. Most of its natives, The Maasai community have religiously observed their culture and traditions despite being surrounded by other 'more civilized communities' (Morompi et al., 2020). They have several cultural events, lifestyle and traditions. Their mode of dressing, hospitality and songs lure thousands of tourists from within and outside the country (Morompi et al., 2020). The famous Maasai male rite of passage ceremonies (Enkipata, Eunoto and Oleng'esherr) which are held at the initiation or graduation of age-sets also attract many tourists and filmmakers. The county also houses a national museum, The Maa museum. Here, there is a gallery of exhibitions collected over the years from the county. Some of these exhibitions include relics, artifacts, paintings, curio and pictures of the Maa people and their associates. The museum also houses exceptional ethnographic portraits by famous international artists. The museum has a traditional botanist who aids in identification of botanical names for plant specimen collected in the area. This is particularly useful especially for botanical researchers and students from the nearby tertiary institutes.

Narok county has several conservancies located around Maasai mara national reserve. Most of these conservancies are found on the gateway to the national reserve (past Ole Sekenani) towards the national reserve. These conservancies have vast rangelands and dispersed areas with shreds of stray wild life and a natural serenity similar to the one in the reserve. Alongside tourism camps, the conservancies are home to Maasai traditional dancers who welcome tourists to the national reserve. The primary goal of these conservancies is to protect the Mara eco-system for mutual benefit of its residents and the reserve. Some of the conservancies include: Olare Orok conservancy (with Ntiakitiak gorge, acacia woodlands and wild animals), Ol Kinyei conservancy (with Porini camp and Porini Cheetah camps), Mara Naboisho (with intense wild animals and bird species), Enonkishu conservancy (with incredible game views) and Mount Suswa conservancy (with perfect caves, camps and natural trails) amongst others (Porini, 2020).

\section{Methodology}

\subsection{Study Design}

The study adopted a cross-sectional research design with the research being conducted in the month of June, 2020. This month was chosen for being the month just next to economic resumption in Kenya. The 3 previous months had witnessed a lot of travel restrictions leading to a slump in the economy and it was expected that this would come to an end on $6^{\text {th }} \mathrm{July}$, 2020. Therefore, June was the worst month (as far as economy and travelling was concerned). The study was conducted in Narok county targeting the localities which receive more tourists. This included: Narok town (with Maa national museum, the county tourism offices, curio shops and several tourist hotels), Ole Sekenani gateway (with a conservancy, camps and tourism hotels), Loita (with conservancies and camps) and in Maasai mara national reserve. 
The target population was tour guides, hoteliers, tour firm operators, cultural groups, museum curators, county tourism officers, curio shops, tented camps and lodge operators and cultural groups.

\subsection{Sampling Techniques and Size}

Purposive sampling was used in this study. The method was used so as to get credible findings from the exact respondents. For example, there are many hotels in Narok county. However, not all can accommodate foreign tourists. These hotels regarded as 2 -star and below might not give the true picture of the situation. This also reduced time and finance used in sampling process. The target respondents were identified and alerted in advance prior to the actual sampling with the help of research assistants. The initial target of the respondents of the study had very many respondents due to the high involvement of tourism and hospitality stakeholders in Narok county. The target population could not be wholly analyzed and was therefore reduced to 81 samples. The sample size was arrived at from Slovin's formulae (Glen, 2020) outlined in equation 1.

$$
n=\frac{N}{1+N\left(e^{2}\right)}
$$

Where, $\mathrm{n}$ is sample size, $\mathrm{N}$ is population size, e is error term $(5 \%)$ based on $95 \%$ confidence interval. The samples were spread out across the various wards (5) in the town. The 81 samples were evenly distributed to the nine types of respondents i.e. tour guide, hoteliers, tour firm operators, cultural groups, museum curators, county tourism officer, curio shops, tented camps and lodges and tour drivers.

\subsection{Research Questionnaires, Interviews and Observation}

The study involved use of questionnaires guides, interviews guides and observation. Questionnaires were given out to literate respondents. The questionnaires were unstructured and had both open ended and closed research questions. The questionnaires were divided into 3 main sections i.e respondents biodata section, information on the tourism and hospitality sector and a section involving effects of Covid-19 pandemic on the sector. The researchers guided the respondents on the areas needing interpretation or any other assistance. For illiterate respondents, the researchers took the respondents through the study via interviews guides. The structure and content of the guides was similar to that of the questionnaires. Both the questionnaires and interview guides were designated to collect the same type of data. Observations were made to assess some of the situations that could easily be noticed. There was no clear structure or number of research items in an observation guide but rather researchers' opinion on notable features of respondents and the sector.

\subsection{Validity, Reliability, and Data Analysis}

Questionnaires were quite reliable since they were easy to administer and encouraged confidentiality thus, reducing biasness. Interviews enabled the use of open-ended questions that aided in acquiring reliable findings and more detailed answers. Both were subjected to the test-retest reliability method to check for their consistency in results after a duration of 8 days. A group of 15 respondents (volunteers) was used. There was a similarity index of $63 \%$ in the results at the two instances of testing. Observation also ensured gathering of reliable data. The 15 respondents were also assigned with the same task and a $67 \%$ similarity index observed. A face validity of the research guides was conducted by 5 volunteers. A pilot study was then conducted to determine the validity of the data collection instruments used. Each of the 44 initial distinct research questions in the questionnaire guide (excluding bio-data section) was assigned to 3 different respondents. In total, there were 132 respondents (volunteers). The data was then debugged and the minimum and maximum values recorded. 
After a critical analysis check, 10 questions were found to be confusing and leading. These questions were plucked out. The ultimate validity score was thus 34/44 (77\%) and the outcomes were found to strongly favor the use of these research guides.

The data collected was analyzed and presented using descriptive statistics. The data collected was analyzed using Ms Excel (2016). For the significance levels, a confidence level of $95 \%$ was used.

\section{Results}

\subsection{Biodata of Stakeholders}

The tourism and hospitality sectors in Narok county were dominated by middle-aged clients between the age of 31 to 50 years. About $40 \%$ of the respondents were in the age bracket of 41 to 50 years while another $37 \%$ were aged between 31 to 40 years. These findings closely related to those of Sikawa (2019) who evaluated the factors affecting tourism performance in Kenya compared to South Africa. This is an indicator that the sector had mature professionals. According to Leitão et al., (2019), the age of employees is directly related to the viability of a job sector. Job sectors with youthful people are assumed to be low-paying and the employees there perceived to be starters in the sector. For example, the informal sector, especially small economy enterprises have a lot of youthful people. The average daily wages in this sector is lower compared to other sectors. On the other hand, most government institutes, organizations and parastatals have workers between 31 to 50 years (prime working age) (Schaaf et al., 2019). These workers are perceived to have more experience and are thus payed more. The occurrence of tourism and hospitality workers in Narok in this age bracket is thus an indicator that the sector has matured and is well-paying (Leitão et al., 2019). Only 13\% of the workers were younger than 30 years old. $3 \%$ of the workers were however older than 50 years old, with all being younger than 60 years. Lack of older staff in the sector can be attributed to the nature of activities in the sector. Most of the activities in the sector were quite involving for example booking clients, guiding them around the destination sites, preparation of food and accommodation, driving them to and from their destinations and others. Most of the activities are performed for long hours. About $70 \%$ of the sector staff were male. Majority of the sector activities such as tour guiding, driving, artisanry involved in curio shops are regarded as 'male-activities'. This is a false perception that has been ongoing for quite some time. This perception is partially because of the background of the Maasai natives who believe that females should only do lighter duties. The few females in the sector $(30 \%)$ were involved in the hospitality sector (mainly in the hotels, camps and lodgings). Only $10 \%$ of the respondents had not married while $90 \%$ of them were married.

\subsection{Background Information Regarding the Tourism and Hospitality Firms}

About $78 \%$ of the respondents worked in this sector permanently. The rest (22\%) did other activities and worked in the sector as a part-time endeavor. The relatively high number of participants in the sector is an indicator of good returns in the sector. When employees find job satisfaction, they tend to concentrate on one job. Majority of the respondents who were engaged as part-time workers in the sector hoteliers working in night shift. This group of respondents could comfortably manage other jobs during the day at ease. Only $6.6 \%$ of the workers in this sector had joined before 2001 (see figure 2). This is attributed to a poor working environment and slow economic growth. 


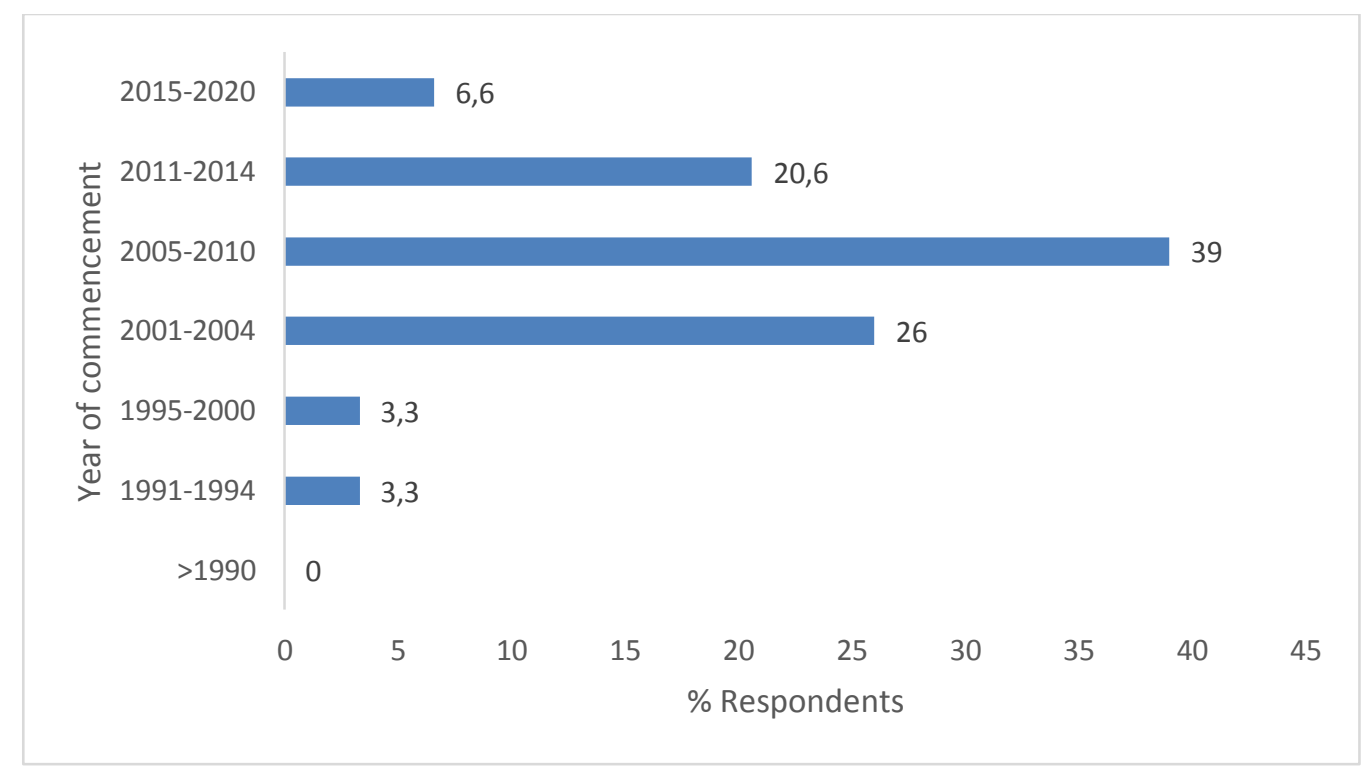

Figure 1: Year of commencement into the sector by tourism and hospitality stakeholders in Narok county

Most of the employees in the sector begun working between 2005 and 2010. Most of the respondents in the bracket had begun in the duration between 2005 and 2007 when the Kenyan economy was booming (Awiti, 2014). Most of the other sectors in the government were booming and the trickle-down effect was also realized in tourism and hospitality sector. There was a slight disruption in the trend in the year 2007 and 2008 due to post-election violence witnessed at the time (Johnson et al., 2014). However, the economy picked up well thereafter and there were more stakeholders in the sector. There was a peaceful business environment between 2001 and 2004 which led to the high increment in the number of employees in the sector. During this period, a new government had taken over in the country and the economy was quite vibrant. Manzoor et al. (2019) attributes growth of tourism and hospitality industry to economic growth and a peaceful working environment. The years following 2010 saw the number of stakeholders in tourism sector gradually decreasing. The number of workers who began working in the sector after 2015 is quite worrying (6.6\%) and this is attributed to a slow economic growth in this duration. The general elections held in the country in 2017 affected the economy slowing the number of stakeholders willing to engage in the sector. Thereafter, the government of Kenya focused on long term infrastructure projects such as building the Standard Gauge Railway, Lamu port amongst others at the expense of other sectors (LAPSSET, 2020). This decreased the spending power of local tourists in Kenya thus lowering the number of stakeholders engaging in the sector. Nevertheless, this did not prevent the revenues from the sector from growing. This can be attributed to the impact of foreign tourists in Narok county. The county enjoyed a wide diversity of foreign tourists (see figure 2). 


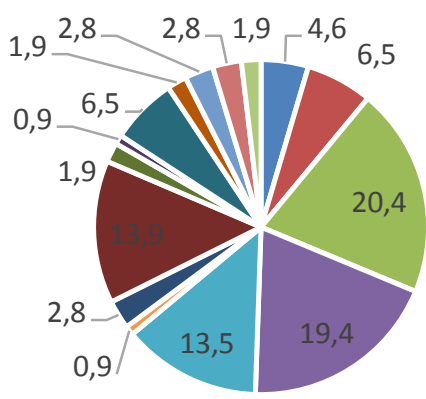

$\begin{array}{lllll}\text { - france } & \text { - germany } & \text { - USA } & \text { - Britain } & \text { - Italy } \\ \text { - Turkey } & \text { - Ireland } & \text { - Spain } & \text { - Japan } & \text { - Brazil } \\ \text { - China } & \text { - Canada } & \text { - India } & \text { - Netherlands } & \text { - Australia }\end{array}$

Figure 2: The countries where majority of foreign tourists originate from.

The respondents indicated that majority of their clients were from USA, Britain, Italy and Spain. About 35\% of the local tourists were from Nairobi county while $25 \%$ of them were from Narok county (see figure 3). The number of customer countries and counties was informed by their spending power. People in nations or counties with a higher poverty index prioritize other basic needs such as food and shelter over tourism. This is because the sector is regarded as a leisure activity.

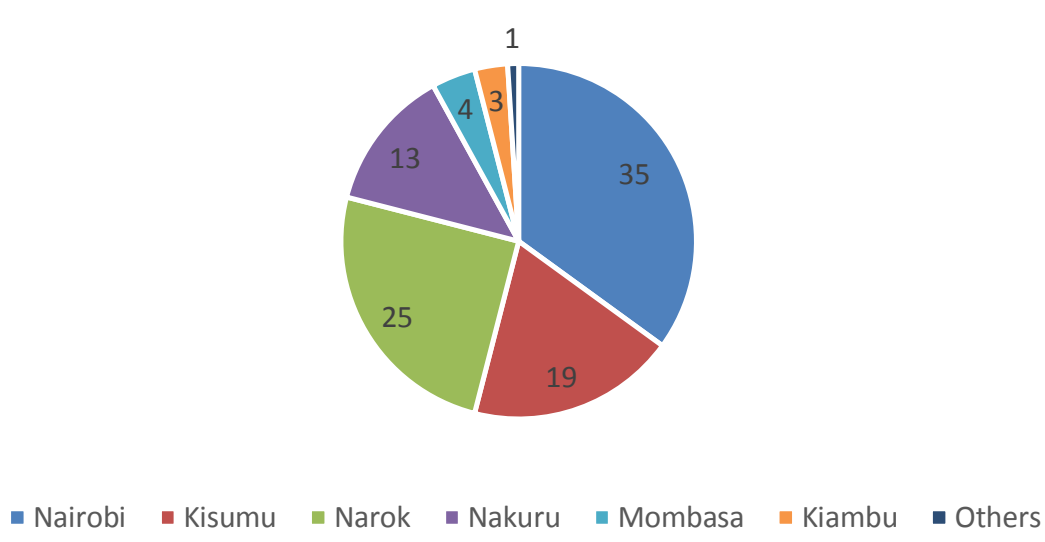

Figure 3: The counties where majority of domestic tourists originate from.

About two-thirds of the respondents had some education pertaining tourism and hospitality industry. The other one-third involved curio shop attendants, some drivers and camp or lodge managers. Most of these were in the sector as a business, having acquired capital or knowledge to manage it from elsewhere. About 35\% of the educated stakeholders in the sector had a diploma or higher diploma. $30 \%$ of the respondents had a certificate while $30 \%$ had a degree on tourism and hospitality management courses. Most of the degree and diploma holders were in management of the enterprises. About $5 \%$ of the respondents attested to having a masters degree in tourism and hospitality courses. These group was also in management or working in the county government.

\subsection{Effects of Covid-19 Pandemic on Tourism and Hospitality Sector}

About $73.3 \%$ of the stakeholders were in contact with their long-term clients. Most of them still maintained close communication via social media tools such as Facebook, Telegram and WhatsApp. $26.7 \%$ of the clients were no longer in communication with the stakeholders. 
Most of the respondents feared that their clients might have contracted corona virus and possibly died. Close contact between the stakeholders and their clients is key in maintaining the longevity of their enterprises. A deeper insight into their communications revealed that only $31.6 \%$ of the clients were willing to resume after the pandemic is over. A whopping $68.4 \%$ of them indicated that they would not be travelling into the county anytime soon. This is a worrying figure if their communications are to be taken seriously. The clients gave several reasons for their non-resumption. $65 \%$ of them were still concerned about the pandemic and feared contracting it while travelling. Though most of the respondents' original countries or counties (Lai et al., 2020) were affected by the pandemic more than Narok county, they believed that there was less precaution measures taken. Others still believed that there were higher chances of contracting the disease while travelling compared to staying at home. Some of the foreign clients felt that Kenya was not sampling enough residents to be tested for the virus. They felt that the figures given by the Ministry of health were not the true reflection of the affected people in Kenya. $20 \%$ of the clients who were not willing to resume to the county indicated that the pandemic had affected their economic status. The money used for tourism had been allocated to other more pertinent needs. They therefore were not in a position to travel and tour the tourism destination sites. Most of this were domestic tourists. $15 \%$ of the respondents who were not willing to travel back indicated that they feared travel restrictions placed by governments. Most of them were foreigners. One of the stakeholders explained the scenario;

.... when they leave their countries for Kenya, they must be tested for the virus. At the various international stop-overs, they will be checked for Covid-19 symptoms or re-tested for the virus. Upon reaching Kenya, they are again checked for covid-like symptoms. Assuming one has some of the symptoms, they would be forcefully quarantined or isolated. This, would waste their time and resources...

Majeed et al. (2020) indicated that travel and tourism are inseparable. If people cannot travel, then they cannot tour. Although the restrictions placed by the governments are good for their people, they affect tourism and hospitality adversely.

\subsection{Effect of the Pandemic on the Services Provided}

About $45 \%$ of the stakeholders in the sector had already turned into other professions to earn a living. This was incited by the drastic drop in revenue (actually to a dead halt for most of them) in the sector. The respondents were caught unaware by the pandemic and had not saved enough to use during the pandemic period. Some of these respondents had either been laidoff, forced into compulsory unpaid leave or furloughed their salary to meagre amounts. These employees had no option but to indulge into other activities to sustain their basic needs. 15\% of the stakeholders had fully quit the profession and turned to another one while $40 \%$ were still in the profession. This number, they said would decrease if the situation was to persist for a longer time. Asgary et al. (2020) notes that poor preparedness and management towards risks lead to such behavior (change in profession). However, 55\% of those who had quit the profession as a whole or for a short time indicated that they would resume to the sector in future. One of the curio shop owners who had converted his premises into a kiosk was quoted saying that;

...if tourists from foreign nations start flocking back; which I presume not to be in the near future, then I will stock out the kiosk items and stock back my artifacts. Until then, I have fully quit that sector. I am not impressed by 
resumption of domestic tourists because they bargain too much leaving me with little profit...

About $45 \%$ of those who had quit the profession partially or fully indicated that they had fully quit the sector and would never indulge in it even if it blossomed in future. Those still in the sector were forced to change their pricing to accommodate the few clients available. Out of these, $89.7 \%$ had reduced the prices of their services. This was a means to attract clients so that their enterprises would be sustained through the pandemic. They were hopeful that normalcy would resume and their enterprises start realizing profits again. $10.3 \%$ of the stakeholders were yet to reduce their pricing charges. This move, they said was informed by the tough times and felt that price reduction would fully affect their operations. They claimed they were already making losses even with these charges. No stakeholder had increased the price of their services.

\subsection{Effect on Employees}

One of the government requirements for opening up of eateries and other social enterprise joints where tourists visit was compulsory testing of the workers (NPR, 2020). The workers were expected to be covid negative in order not to transfer the virus to their clients. Testing fee was to be met by the enterprises or the individual worker; depending on their agreement. This move was not very welcome in Narok county which did not have a single confirmed covid case by then. This rule was thus largely defaulted. Only $11 \%$ of the employees confirmed to have undergone the test and were confirmed covid-negative. $21 \%$ of the employees who were still in operation indicated that they had not undergone the test. Asked why they were comfortably working despite the illegality, one of the respondents answered that;

...why worry about covid? There is no covid in Narok. Even the figures announced by the $\mathrm{MOH}$ (ministry of health) are by far exaggerated. Additionally, if the police will come to close down my enterprise, I will simply tip him/her with about Ksh. 200 and be safe. There is no cause for alarm...

About $68 \%$ of the respondents did not wish to disclose whether they had tested for corona virus. Most of these respondents thought that they would be exposed if they agreed not to have tested for the virus. They feared that the researchers would inform the necessary authorities who would come to close down their enterprises again. The number of employees in various tourism destination sites in the county drastically reduced after the pandemic. Only $41 \%$ of the destinations had less than 10 employees before the pandemic. This ratio increased to $79 \%$ after the pandemic as the enterprises strained to sustain themselves thus forcing some of their staff into compulsory leave or laying them off. Out of the $29 \%$ of the enterprises with 11 to 20 employees, only $16 \%$ had this number after the pandemic. A similar decline in employees was also observed for firms with 21 to 30 employees (see figure 5). 


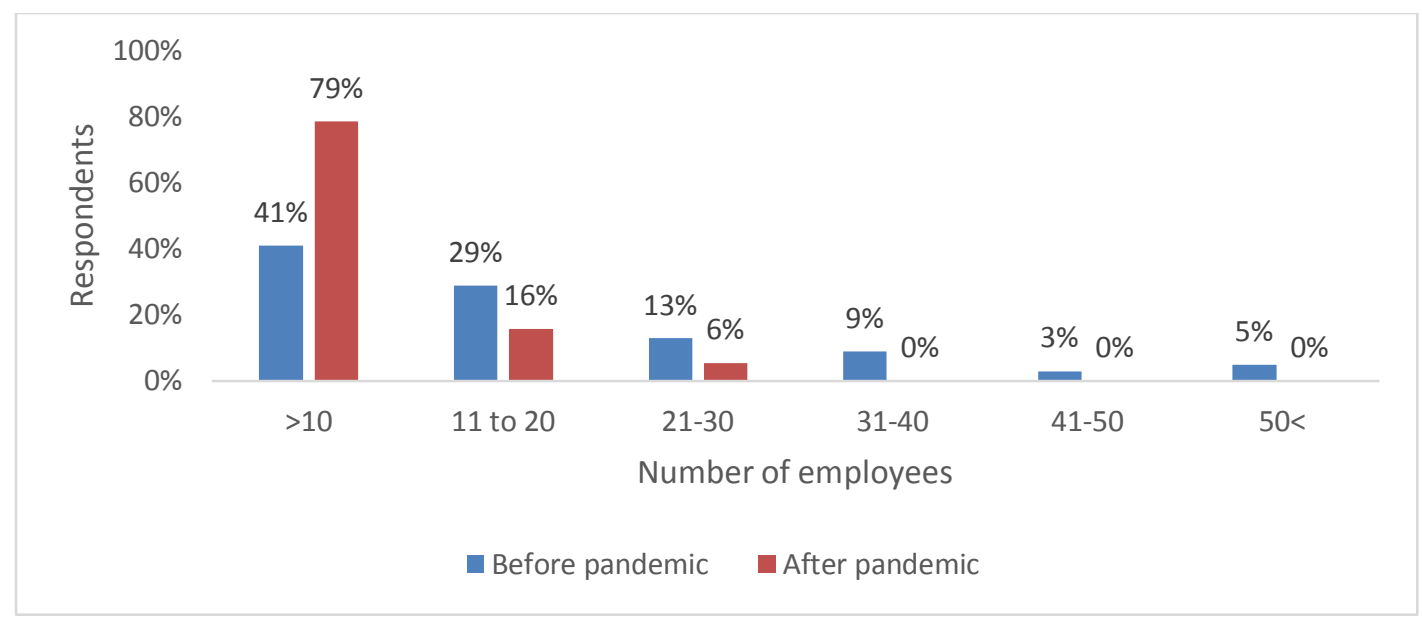

Figure 5: Effect of Covid-19pandemic on number of employees.

There was no tourism destination with 30 employees and above in Narok county during the month of June, 2020. All the firms who had these employees before the pandemic had reduced their number or sent away others. Reduction in employee was because the firms could not meet their wage-bills.

\subsection{Effect on the Clients}

The number of clients visiting tourism destination sites in the county also decreased dramatically. Before the pandemic, only $4 \%$ of the sites received 1 to 5 tourists daily. After the pandemic, this number skyrocketed to $61 \%$. The stakeholders were however grateful for this number which they preferred to having no clients. Most of the destination sites had between 11 to 30 clients daily. $84 \%$ of these clients were reduced to between 1 to 10 clients daily (see figure 6).

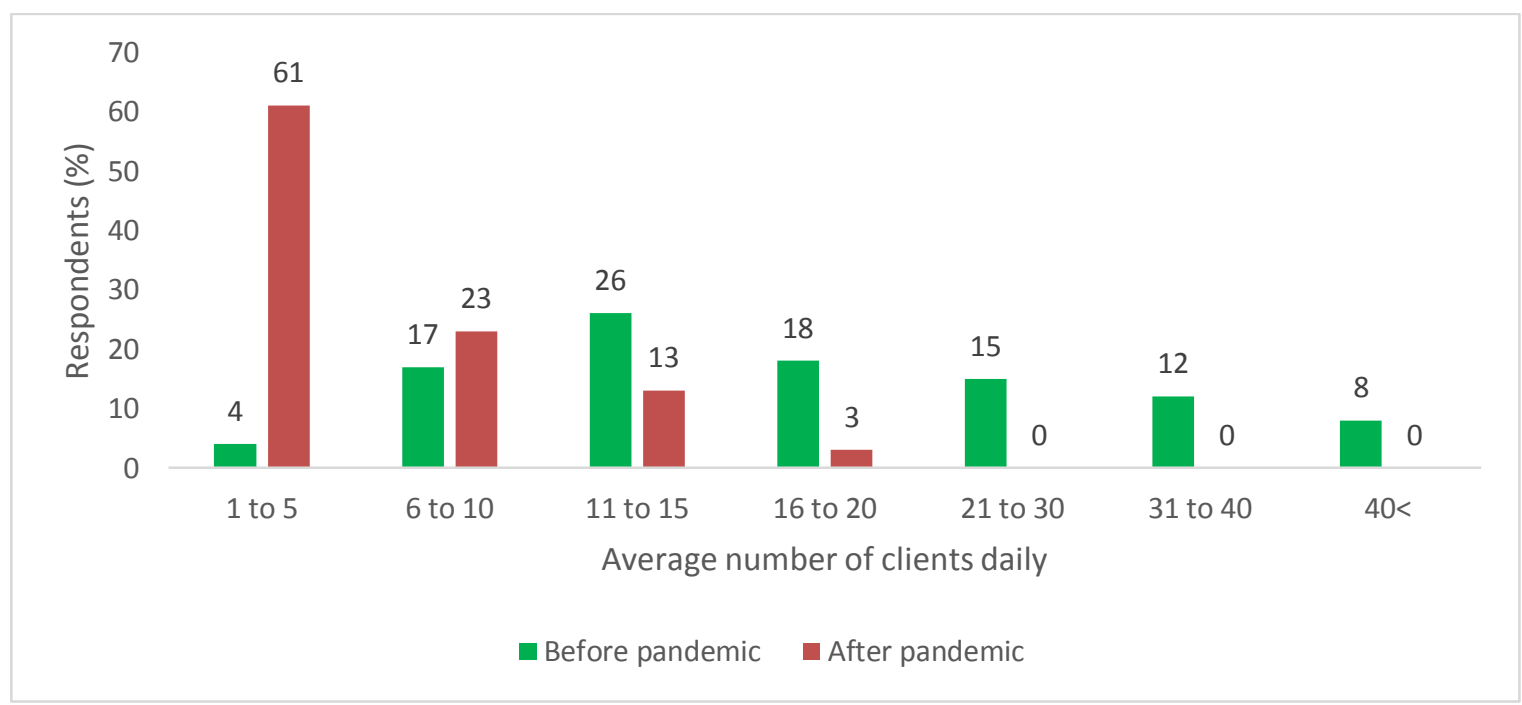

Figure 6: The average number of clients visiting tourism destination sites in Narok county.

There was no tourism destination site that recorded more than 21 clients daily within June, 2020 in the county. This is a massive downfall from the cumulative 35 clients daily visiting the destination sites before the pandemic. The large decline in clients has a direct negative toll on the livelihood of the stakeholders. However, on a more positive notch, the decline in daily clients will give the wild life (both flora and fauna) time and space to blossom (Hunter, 2007). 
Reduced human pressure will enable the birds and animals to multiply as the other eco-system also heals. Such a break would not have been possible with human pressure on the eco-system (Avecedo-Whitehouse and Duffus, 2009). Some of the destination sites also took the advantage to clean up and refurbish some of the worn-out systems and infrastructure. Others had to re-strategize on better product promotion strategies to lure customers. To minimize chances of contracting corona virus, $\mathrm{MOH}$ officials advised on reduced usage of cash for transactions. They advised people to use other methods such as mobile money transfer and online transfers. This was also observed by the few clients who visited the destination sites. Use of cash reduced from $36 \%$ to $15 \%$ while that of mobile money transfer by MPESA and Airtel Money increased by $30 \%$ and $7 \%$ respectively. Use of MPESA was thus significantly higher than that of Airtel Money $(P>0.05)$. This is regardless of Airtel Money having cheaper charge tariffs compared to MPESA. MPESA's dominance over Airtel Money was justified by the numerous clients of its mother company, Safaricom network provider. The high margin is also attributed to the network strength of the latter compared to Airtel (Tripadvisor, 2018). The two entities were however lucky to get a boost in customers as revelers and tourists prioritized them over contact money transactions (cash). Use of debit and credit cards reduced by a margin of $15 \%$. This can be justified by the reduction in foreign tourists who were the main users of this mode of money transfer. The same can be explained with reduction in use of Paypal and other online money transfers. The change in modes of money transactions in the county due to Covid-19pandemic (see figure 7).

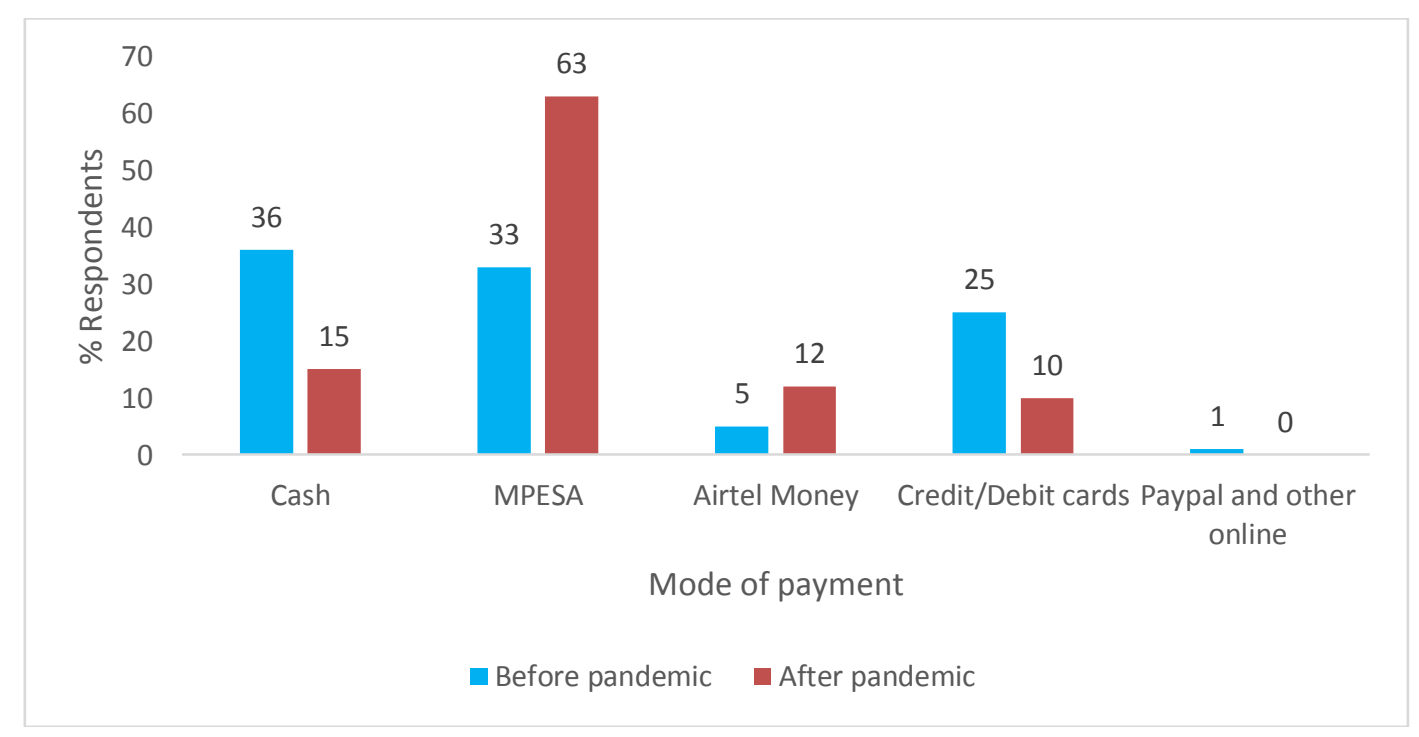

Figure 7. Effect of the pandemic on mode of money transactions in Narok county.

There was no significant change in tourists' destination site due to the pandemic ( $\mathrm{P}<$ 0.05). The few clients who visited preferred the same destination sites visited before the pandemic. Maasai Mara national reserve was by far the most preferred destination $(89 \%$ and $88 \%$ before and after the pandemic). This, they indicated was because watching wild life was their key interest. The tourists claimed that other tourist attraction activities could be satisfied elsewhere. It was however not possible to observe most of the wild life from other destinations. Visit to tourist camps fell by a slight margin (2\%) with the tourists citing less finance as the key reason. They claimed most of the camps were expensive and were only interested in game drives while in the park. Some also cited fear of congregation in the camps which would increase their chances of contracting corona virus. There was a slightly higher demand for conservancies, museums and curio shops. This also informed by the tourists' finances and closeness to these destination sites. For example, tourists from Narok town 
would spend less in terms of travel to visit the Maa museum, a conservancy or curio shop compared to camps located inside the game reserve (see table 1).

Table 1: Effect of the pandemic on clients preferred tourism destination sites.

\begin{tabular}{|c|c|c|}
\hline Preferred tourism destination site & \multicolumn{2}{|l|}{ Respondents (\%), n= 81 } \\
\cline { 2 - 3 } & $\begin{array}{l}\text { Before the } \\
\text { pandemic }\end{array}$ & After the pandemic \\
\hline Maasai Mara national reserve & 89 & 88 \\
\hline Tourist camps & 6 & 2 \\
\hline Conservancies & 1 & 3 \\
\hline Museum & 3 & 5 \\
\hline Curio shops & 1 & 2 \\
\hline
\end{tabular}

The change preferred mode of transport was also quite minimal. Majority of the tourists still preferred using tour land rovers. This choice had increased from 71 to $73 \%$. The persistence in this choice of transportation was informed by spending power, safety, comfort and availability of these land rovers. Out of the $9 \%$ clients who used air previously, only $2 \%$ still preferred the option. Air transport was mainly reserved for the 'wealthier' class in society. Use of buses had to visit tourist destinations had increased from 11 to 19\%. This method, most of the clients claimed, was by far cheaper; though not as comfortable as land rovers. One of the respondents narrated that;

...you can hire a school bus as a big group. During a wedding, anniversary, graduation or whichever ceremony. A 62-seater bus can go for less than Ksh. 50,000 for one day. However, a land rover can only carry up to 7 clients and the driver at around Ksh. 15,000. Therefore, for 62 people, more than Ksh. 100, 000 (double the amount used by a bus) is required. This are difficult times which require shrewd economic decisions to survive. Most clients therefore prefer to use buses...

Use of small private (family) cars had also reduced from $6 \%$ to $2 \%$ since they were also more expensive. It is therefore obvious that clients' mindset and decisions going forward mainly prioritized economic aspects and safety; not comfort. This was witnessed by the change in clients' perception towards tourism destination sites, mode of transactions and travel.

\subsection{Effect on the Stakeholders' Income}

All the changes resulting from the pandemic were properly manifested in the stakeholders' monthly profits. Before the pandemic, no tourism destination site would get less than Ksh. 10,000 per month. Actually, more than half $(60 \%)$ of the sites made net profit margins in excess of Ksh. 40,000. This number was reduced to only $3.5 \%$ after the pandemic. Several reasons can be attributed to the loss. Poor customer turnout due to harsh economic times and fear of travelling or congregating was the key reason of the drastic drop in profits (Welfens, 2020). About $33 \%$ of the destination sites made net profit margins of between Ksh. 21,000 and 40,000 . This sites also had their profits reduced with only $6.8 \%$ of the group realizing the same profits after the pandemic. The majority of the destination sites made less than Ksh. 10,000 profits after the pandemic. This was very little, bearing in mind that they had already laid-off and furloughed some workers. It is for these reasons that some of the entities were partially or fully shut down. The distribution in profit margins made by the tourism destination sites in Narok county thus decreased significantly $(\mathrm{P}>0.05)$ (see table 2 ). 
Table 2: Effect of the pandemic on tourism and hospitality stakeholders' monthly income.

\begin{tabular}{|c|c|c|}
\hline Average monthly income (Ksh.) & Respondents (\%), $\mathbf{n = 8 1}$ \\
\cline { 2 - 3 } & Before the pandemic & After the pandemic \\
\hline$<10,000$ & 0.0 & 65.5 \\
\hline $11-20,000$ & 6.7 & 24.1 \\
\hline $21-30,000$ & 10 & 3.3 \\
\hline $31-40,000$ & 23 & 3.5 \\
\hline$>40,000$ & 60 & 3.5 \\
\hline
\end{tabular}

About $35 \%$ of the stakeholders still had bank loans to clear. A good number of them indicated that it was practically impossible to clear the loans in the timelines specified by their lenders. Some feared of having their assets being auctioned or loan-collateral being taken by the financial lenders because they did not anticipate to pay back soon. On a better note, 53\% of the entities were insured. None of the entities was however insured against pandemics such the Covid-19 pandemic.

\section{Conclusions, Implications and Limitations}

Over $70 \%$ of the stakeholders were in close contact with their clients. Only $31.6 \%$ of the clients indicated willingness to resume after the pandemic was over. Majority of the stakeholders cited harsh economic times and fear of contracting corona virus as the barriers for their re-visits. Some of the stakeholders had changed to other professions; partially or fully. Most tourism destination sites had either laid-off workers, sent them on compulsory leave or furloughed their salaries. The average daily number of clients visiting tourism destination sites had reduced by about $84 \%$. The clients had also changed their mode of money transaction. There was little change in their mode of travelling and preferred destination sites. The stakeholders profit margins had drastically reduced to unbearable figures. It was evident that Covid-19 pandemic had truly affected tourism and hospitality sector in the county.

This study implied that drastic measures need to be taken to save tourism and hospitality industries from fully collapsing. Should the current trend proceed for a few more months, then the sectors might be permanently affected. Millions of jobs and revenue obtained through the sector are also likely to be lost. Additionally, other sectors related to tourism and hospitality sectors are also likely to be affected.

The stakeholders indicated that the county and national government should actualize their words of cushioning them during these difficult moments. The stakeholders play a very big role of generating revenue for the county, employing county and national residents and conserving the Mara eco-system. It is therefore very unfair for the county to abandon them during this hour of need. Apart from tax waivers, the stakeholders indicated that they required a monthly stipend to sustain their basic needs as well as those of their employees. The government should also promote domestic tourism as it is the most reliable one at the moment.

This study was limited to the area and duration of study. The impacts of Covid-19 pandemic on tourism and hospitality sectors affected many parts of Kenya in different ways. This is because different tourism destinations have different tourist clients (domestic or foreign) and are thus affected differently. Some of the tourism destination sites also experienced the effects of Covid-19 pandemic at different times. However, this study brought into light a general perspective of how the pandemic had affected this crucial part of the economy. 


\section{References}

Acevedo-Whitehouse, K. \& Duffus, A. (2009). Effects of environmental change on wildlife health. Philosophical transactions of the Royal Society of London. Series B, Biological Sciences, 364(1534), 3429-3438. https://doi.org/10.1098/rstb.2009.0128.

Asgary, A., Ozdemir, A. \& Özyürek, H. (2020). Small and Medium Enterprises and Global Risks: Evidence from Manufacturing SMEs in Turkey, International Journal of Disaster Risk Science, 11, 59-73. https://doi.org/10.1007/s13753-020-00247-0.

Awiti J. (2014). Poverty and health care demand in Kenya, BMC Health Services Research, $14,560$.

Bloom, D. \& Cadarette, D. (2019). Infectious Disease Threats in the Twenty-First Century: Strengthening the Global Response, Frontiers in Immunology, 10, 549. https://doi.org/10.3389/fimmu.2019.00549.

Cohn S. (2012). Pandemics: waves of disease, waves of hate from the Plague of Athens to A.I.D.S. Historical Journal (Cambridge, England), 85(230), 535-555.

Dobson A. (2009). Food-web structure and ecosystem services: insights from the Serengeti. Philosophical transactions of the Royal Society of London. Series B, Biological sciences, 364(1524), 1665-1682. https://doi.org/10.1098/rstb.2008.0287.

Gakuya, F., Ombui, J., Heukelbach, J., Maingi, N., Muchemi, G., Ogara, W., Mijele, D., \& Alasaad, S. (2012). Knowledge of mange among Masai pastoralists in Kenya. PloS one, 7(8), 1-7. https://doi.org/10.1371/journal.pone.0043342.

Gössling, S., Scott, D. \& Michael, H. (2021) Pandemics, tourism and global change: a rapid assessment of COVID-19, Journal of Sustainable Tourism, 29(1), 1-20, DOI: 10.1080/09669582.2020.1758708.

Hunter P. (2007). The human impact on biological diversity. How species adapt to urban challenges sheds light on evolution and provides clues about conservation, EMBO Reports, 8(4), 316-318. https://doi.org/10.1038/sj.embor.7400951.

International Monetary Fund, IMF. (2020). Policy Responses to COVID-19. Retrieved from https://www.imf.org/en/Topics/imf-and-covid19/Policy-Responses-to-COVID-19. Accessed on 25th November, 2020.

Johnson, K., Scott, J., Sasyniuk, T., Ndetei, D., Kisielewski, M., Rouhani, S., Bartels, S., Mutiso, V., Mbwayo, A., Rae, D., \& Lawry, L. (2014). A national population-based assessment of 2007-2008 election-related violence in Kenya, Conflict and Health, 8(1), 2. https://doi.org/10.1186/1752-1505-8-2.

Lai, C., Wang, C., Wang, Y., Hsueh, S., Ko, W. \& Hsueh, P. (2020). Global epidemiology of coronavirus disease 2019 (COVID-19): disease incidence, daily cumulative index, mortality, and their association with country healthcare resources and economic status, International Journal of Antimicrobial Agents, 55(4), 105946. https://doi.org/10.1016/j.ijantimicag.2020.105946.

LAPSSET. (2020). Railway - LAPSSET Corridor Development Authority. Retrieved from http://www.lapsset.go.ke/projects/railway/ Accessed on $16^{\text {th }}$ August, 2020.

Leitão, J., Pereira, D., \& Gonçalves, Â. (2019). Quality of Work Life and Organizational Performance: Workers' Feelings of Contributing, or Not, to the Organization's Productivity, International Journal of Environmental Research and Public Health, 16(20), 3803. https://doi.org/10.3390/ijerph16203803.

Mackenzie, J. S., \& Smith, D. W. (2020). COVID-19: a novel zoonotic disease caused by a coronavirus from China: what we know and what we don't, Microbiology Australia, 41, 45-50. https://doi.org/10.1071/MA20013.

Majeed, S., Zhou, Z., Lu, C., \& Ramkissoon, H. (2020). Online Tourism Information and Tourist Behavior: A Structural Equation Modeling Analysis Based on a SelfAdministered Survey, Frontiers in Psychology, 11, 599. https://doi.org/10.3389/fpsyg.2020.00599. 
Manzoor, F., Wei, L., Asif, M., Haq, M. Z., \& Rehman, H. (2019). The Contribution of Sustainable Tourism to Economic Growth and Employment in Pakistan, International Journal of Environmental Research and Public Health, 16(19), 3785. https://doi.org/10.3390/ijerph16193785.

Maphanga, P., \& Henama, U. (2019). The tourism impact of Ebola in Africa: Lessons on crisis management. African Journal of Hospitality, Tourism and Leisure, 8 (3). https://www.ajhtl.com/uploads/7/1/6/3/7163688/article_59_vol_8_3_2019.pdf.

Morompi, O., Walingo, M., Osano, A., Bulitia, G. and Bakari, C. (2020). Impacts of neglecting African Traditional Environmental Conservation Practices and education on the environment: A Case of the Maasai People of Narok County, Kenya. International Journal of Innovative Research in Science, Engineering and Technology (IJIRSET), 9(4), 1-10.

Njoya, E., \& Seetaram, N. (2018). Tourism Contribution to Poverty Alleviation in Kenya: A Dynamic Computable General Equilibrium Analysis, Journal of Travel Research, 57(4), 513-524. https://doi.org/10.1177/0047287517700317.

NPR. (2020). Kenya Opens Up Restaurants With New Restrictions. Retrieved from https://www.npr.org/2020/05/20/859261845/kenya-opens-up-restaurants-with-newrestrictions. Accessed on 16th August, 2020.

Novelli, M., Burgess, L. G., Jones, A., Ritchie, B. W. (2018). No Ebola... still doomed'-The Ebola-induced tourism crisis. Annals of Tourism Research, 70, 76-87. https://doi.org/10.1016/j.annals.2018.03.006

Ogutu, J., Piepho, H., Said, M., Ojwang, G., Njino, L., Kifugo, S., \& Wargute, P. (2016). Extreme Wildlife Declines and Concurrent Increase in Livestock Numbers in Kenya: What Are the Causes? PloS one, 11(9), 1-46. https://doi.org/10.1371/journal.pone.0163249.

Porini. (2020). Kenya Camp/Safari Holiday Packages/Gamewatchers Safaris. Retrieved from https://www.porini.com/kenya/parks-and-reserves/ Accessed on 16 ${ }^{\text {th }}$ August, 2020.

Schaaf, M., Maistrellis, E., Thomas, H., Cooper, B., \& GGR Research Working Group (2019). 'Protecting Life in Global Health Assistance'? Towards a framework for assessing the health systems impact of the expanded Global Gag Rule, BMJ Global Health, 4(5), 1-12. https://doi.org/10.1136/bmjgh-2019-001786.

Sikawa, S. (2019). Factors affecting Tourism Performance: A comparative study between Kenya and South Africa, Masters' thesis, USIU University, Kenya.

Siu, A., \& Wong, Y. (2004). Economic impact of SARS: The case of Hong Kong, Asian Economic Papers, 3 (1), 62-83. https://doi.org/10.1162/1535351041747996

Sharma, A., Tiwari, S., Deb, M., \& Marty, J. (2020). Severe acute respiratory syndrome coronavirus-2 (SARS-CoV-2): a global pandemic and treatment strategies, International Journal of Antimicrobial Agents, 56(2), 106054. https://doi.org/10.1016/j.ijantimicag.2020.106054.

Stephanie Glen. (2020). "Slovin's Formula: What is it and When do I use it?" From StatisticsHowTo.com: Elementary Statistics for the rest of us! https://www.statisticshowto.com/how-to-use-slovins-formula/.

Welfens P. (2020). Macroeconomic and health care aspects of the coronavirus epidemic: EU, US and global perspectives, International Economics and Economic Policy, 17, 295362, https://doi.org/10.1007/s10368-020-00465-3.

Western, D., Russell, S., \& Cuthill, I. (2009). The status of wildlife in protected areas compared to non-protected areas of Kenya, PloS one, 4(7), 1-6. https://doi.org/10.1371/journal.pone.0006140.

World Bank. (2020). Air transport, passengers carried. Retrieved April 4, 2020, from https://data.worldbank.org/indicator/is.air.psgr . Accessed on $13^{\text {th }}$ August, 2020. 
World Travel \& Tourism Council, WTTC. (2020), The World Travel \& Tourism Council (WTTC) represents the Travel \& Tourism sector globally. Retrieved from https://wttc.org/. Accessed on $16^{\text {th }}$ August, 2020.

World Travel \& Tourism Council, WTTC. (2020). Government COVID-19 Policies. Retrieved from https://wttc.org/COVID-19/Government-Policies. Accessed on 25th November, 2020

\section{Author Biography}

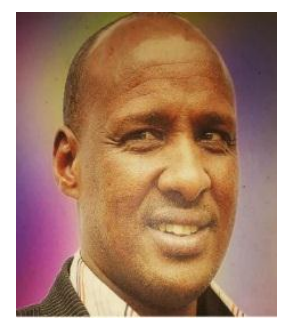

Mr Morompi Ole Masago is a PhD student in the University of Nairobi, Kenya. His area of focus is on preservation of Maasai cultural norms. Mr Morompi obtained his Undergraduate and Masters degree from Maasai mara university. Mr Morompi has done several researches on influence of tourism culture on the Maasai community culture. He is currently the Assistant Dean of Students in the university.

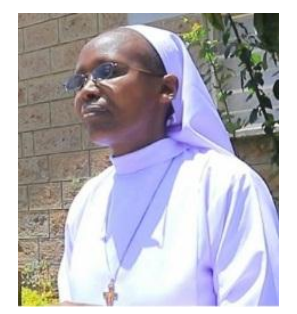

Dr Sr Alice Sambu has a masters and doctorate degree in Theology. She also has a masters degree in Music education and is currently pursuing her doctorate in Music education. She is a senior lecturer in The Department of Religion and Social sciences in Maasai Mara university. She is also the Deputy Dean of Students.

Dr Kweingoti Reuben has a doctorate degree in Theology. He has done extensive research on cross-cutting issues on theology and tourism in Narok county. Dr Kweingoti is the head of the Department of Social Studies and Religion, Maasai mara university.

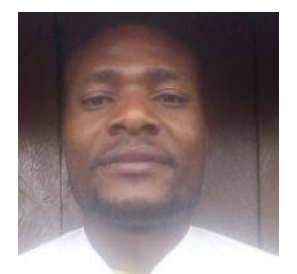

Mr Keiza Kinzi Samson has a Masters degree in Tourism Management. Mr Keiza is an adjunct lecturer in the department of tourism and hospitality in Maasai mara university. Mr Keiza's researches focus on new tourism approaches for a sustainable economy. 
Mr Bakari Chaka has a Masters' of Science in Chemistry from Maasai mara university. Mr Chaka has done extensive works on cross-cutting issues including culture and tourism in Narok county. Mr Chaka is a Research Assistant at the Directorate of Research and Innovation, Maasai mara university. 